\title{
The Influence of Professional Human Resource and Firm Infrastructure towards Supply Chain Performance
}

\author{
Noor Asleena Asnordin, Veera Pandiyan Kaliani Sundram, Shereen \\ Noranee
}

To Link this Article: http://dx.doi.org/10.6007/IJARBSS/v10-i12/8042

DOI:10.6007/IJARBSS/v10-i12/8042

Received: 16 October 2020, Revised: 23 November 2020, Accepted: 05 December 2020

Published Online: 27 December 2020

In-Text Citation: (Asnordin et al., 2020)

To Cite this Article: Asnordin, N. A., Sundram, V. P. K., \& Noranee, S. (2020). The Influence of Professional Human Resource and Firm Infrastructure towards Supply Chain Performance. International Journal of Academic Research in Business and Social Sciences, 10(12), 718-732.

Copyright: (c) 2020 The Author(s)

Published by Human Resource Management Academic Research Society (www.hrmars.com)

This article is published under the Creative Commons Attribution (CC BY 4.0) license. Anyone may reproduce, distribute, translate and create derivative works of this article (for both commercial and non-commercial purposes), subject to full attribution to the original publication and authors. The full terms of this license may be seen at: http://creativecommons.org/licences/by/4.0/legalcode

Vol. 10, No. 12, 2020, Pg. 718 - 732

Full Terms \& Conditions of access and use can be found at http://hrmars.com/index.php/pages/detail/publication-ethics 


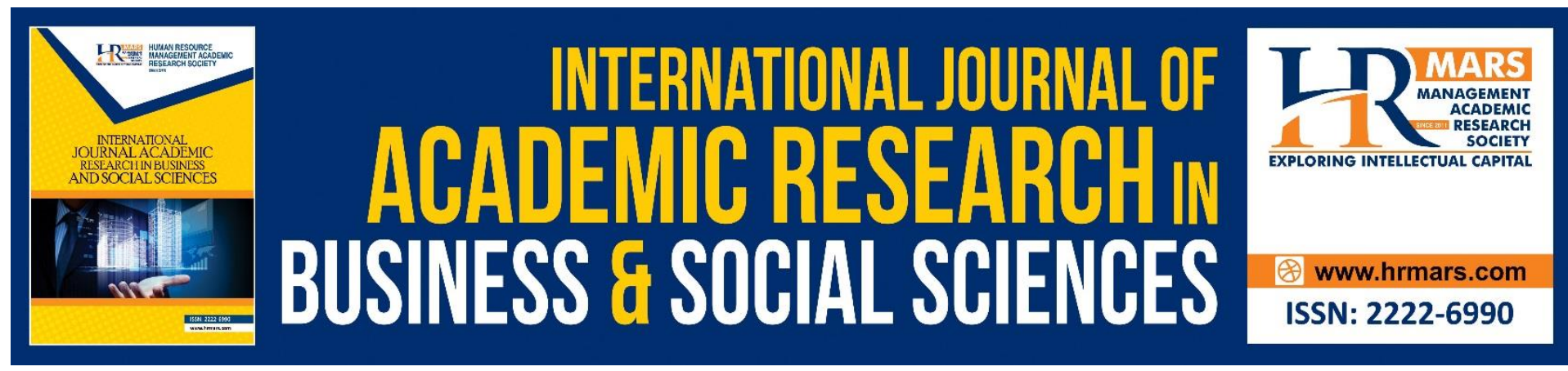

\title{
The Influence of Professional Human Resource and Firm Infrastructure towards Supply Chain Performance
}

\section{Noor Asleena Asnordin ${ }^{1}$, Veera Pandiyan Kaliani Sundram², Shereen Noranee ${ }^{3}$}

\author{
${ }^{1}$ Faculty of Business and Management, Universiti Teknologi MARA, UiTM Kampus Shah Alam, \\ 40450 Shah Alam, Selangor, Malaysia, ${ }^{2}$ Department of Technology \& Supply Chain Management \\ Studies, Faculty of Business and Management, Universiti Teknologi MARA, UITM Kampus Puncak \\ Alam 42300 Bandar Puncak Alam, Selangor, Malaysia, ${ }^{3}$ Faculty of Business and Management, \\ Universiti Teknologi MARA, UITM Kampus Puncak Alam \\ 42300 Bandar Puncak Alam, Selangor, Malaysia \\ Email:meyhmae@yahoo.com, veera692@uitm.edu.my,shereen@uitm.edu.my
}

\begin{abstract}
Human resource management (HRM) practices are integral to organizational performance, productivity and sustainability. Incorporating human resource practices allows a firm to attract and maintain a workforce as well as encourage them to contribute to organizational strategies and goals with the purpose of improving company performance. Meanwhile as supply chains continue to replace individual firms as the economic engine for creating value during the twenty-first century, understanding the supply chain performance becomes increasingly important for both practitioners and researchers. Previous studies have addressed human resource practices and firm infrastructure in separate studies. This conceptual paper will explore the key role played by human resource management practices and firm infrastructure in the effort to succeed within a competitive business environment, and consequently enhance firm performance. Furthermore, the proposed framework will be valuable to various environments due to its integration of prior research and literature. This study is among the pioneers in investigating and determining the conceptual relationship between supply chain performance and human resource practices.
\end{abstract}

Keywords: Professional Human Resource, Firm Infrastructure, Supply Chain Performance.

\section{Introduction}

Supply chain performance is one of the substances of competitive strategy to boost organizational productivity and profitability (Barnes and Liao, 2012; Shabbir and Kassim, 2018; Saudi et al., 2019). Nowadays, supply chain management, analysis, and development are becoming increasingly important. However, still a gap exists, which is needed to be filled to boost up supply chain performance, particularly in Malaysia based companies. Most of the managers in manufacturing organization majorly focus on supply chain performance. As it plays vital role in cost management and overall company's profitability.

Hence, because of the extensive use of gross domestic product (GDP) on supply chain, it is important to work on Malaysia based supply chain companies and to reveal various factors to enhance 
supply chain performance. The firm supply chain performance is merging as the main agenda behind achieving the economies of scale.

Organizational and market performance was driven by supply chain performance most of the time (Adams et al., 2014). Studies on supply chain performance can be classified under two major areas. The first category of research is about how to measure supply chain performance (Sundram et al., 2017; Mkumbo et al., 2019).

The second group of studies focus on several predictor factors that could be used in explaining why some supply chains perform better than others (Rajagopal et al., 2016; Selvaraju et al., 2019). Despite the abundance of research on supply chain performance, but there is little empirical work on the effects of human resource practices on supply chain performance (Hendiani, Liao and Jabbour, 2020).

Professional human resources (PHR) and the supply chain (SC) as fields of study have traditionally been treated separately, despite their being "intimately linked" in almost all business environments (Barnes and Liao, 2012). In fact, Jang and Ardichvili (2020) propose the importance of professional human resource (PHR) related to the area of operations as a new research theme. To ensure the success of their supply chain performance (SCP), firms need to commit themselves fully to promoting this human dimension. Many firms focus their attention on improving and investing in technology and in infrastructure, but they need to dedicate the same attention to the people that manage and operate the SC. For Ou et al. (2010) an adequate HR system is a key element in the implementation of a supply chain and consequently, for greater improvement on operational performance as well as supply chain performance.

Today's human resource (HR) is a unique approach to employment management that aims to attain competitive advantage through the strategic improvement of well dedicated and competent workers by means of an incorporated collection of cultural, structural and human resources techniques. An effective PHR in the organization will enable employees to contribute effectively and fruitfully to the achievement of the organization's goals and objectives. It makes employees to be committed to their work and generate positive behavior that will increase the organization's effectiveness. PHR is expected to add value to the strategic utilization of workforce.

In relationships characterized by supply chain integration, supply chain partners are selected based on their strategic resources. Resource-based theories such as resource dependence theory RDT and the resource-based view RBV explain behaviors among supply chain partners in these hybrid modes of governance. Resource-based theories explain the impetus for interdepartmental integration among business units within firms (Barnes and Liao, 2012; Selvaraju, Beleya and Sundram, 2017) and more recently, integration across firms in a supply chain (Nyaga, Whipple and Lynch, 2010; Hua et al., 2020). Resource Dependence Theory suggests that firms are dependent on other firms to obtain critical resources (Emerson, 1962). Therefore, the firm infrastructure affects the supply chain performance of an organization.

\section{Research Gap}

Based on previous research, there are several gaps that can be identified in the area of professional human resource practices and firm infrastructure in supply chain performance and in supply chain management in general. Moreover, SC also has been distinguished for its strategic role in coordinating business processes across trading partners and simultaneously to improve both the performance of an individual organization (Ralston et al., 2015) and the performance of the entire supply chain (Yu, 2015; Rajesh and Ravi, 2015). In order to compete, supply chain management seeks close integration with internal functions within firm and external linking with suppliers, customers and other channel members. 
This could be achieved through effective construction of various supply chain practices (Huang, Yen and Liu, 2014). Despite knowing the essentials of supply chain, there are still some business organizations who are clueless and do not know precisely what are the sets of supply chain management practices to be implemented to improve the performance (Khajavi, Partanen and Holmstrom, 2014). These cases indicate the necessity for research that is founded on the impact of human resources and firm infrastructure towards supply chain performance.

The study of human resource has gained importance in the literature for the last few years (Sundram, Atikah and Chandran, 2016) and most importantly its impact on organizational performance (OP), effectiveness and employees' commitment. However, there is little in the literature that describes the relationship between human resource and supply chain performance. This omission may perhaps be due to the previously noted initial research emphasis on hard supply chain topics. Further, there is a notable lack of studies that evaluate the soft variables and their alignment with supply chain strategies. From an applied perspective, Anastasiou (2012) suggest that human resource must be proactively applied to the emerging supply chain. Toward this end, Harari, Jain and Joseph (2014) identify new rules for human resource, including permeable boundaries and virtual enterprises. Similarly, Swat and Kinnie (2014) describe the direct and indirect effect that give changes in supply chain performance.

MacDuffie (1995); Huselid (1995) indicated that HR generated better performance only when three conditions were met: when employees possessed well- developed skills, when employees were motivated to apply their skills and when platforms were provided for employees to contribute their efforts. These conditions are known as high-involvement HRM practices and have been confirmed to greatly improve individual (Liu and Batt, 2010), operational (MacDuffie, 1995), firm (Huselid, 1995) and supply chain levels (Fu et al., 2014).

Liu and Batt (2010) explicitly pointed out that high-involvement HRM systems included a set of HRM practices that aimed at advancing employee skills, enhancing employee incentives and improving employee participation. Through selective hiring, potential talents are placed into companies and serve as fundamental resources for companies to compete (Dubey, 2017). 


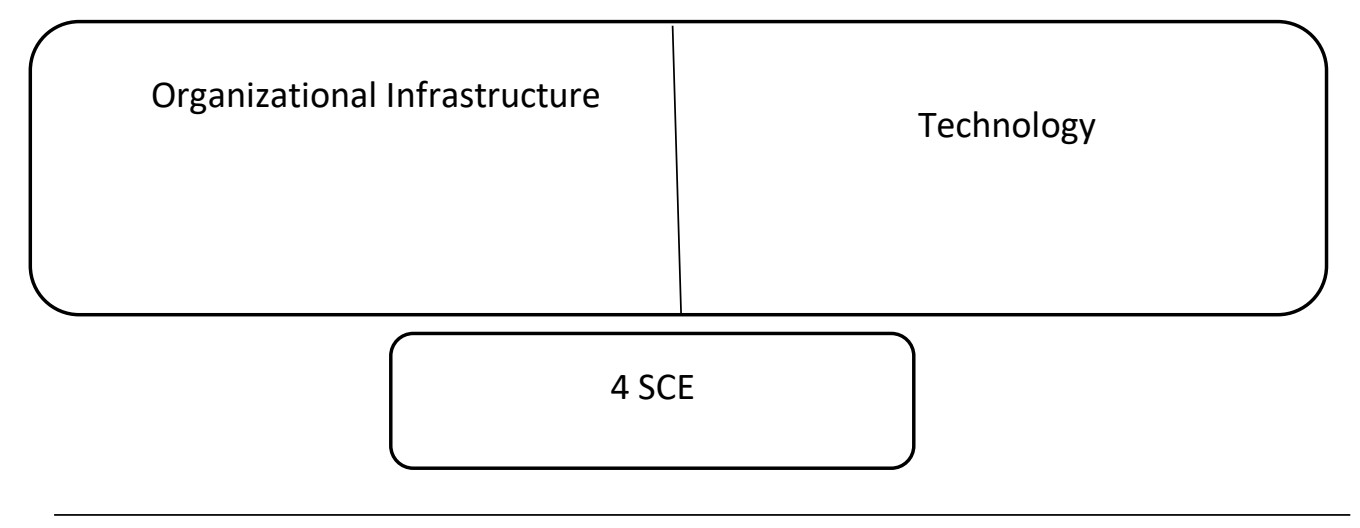

Figure 1. The four key enablers of supply chain

\section{Professional Human Resource}

Human resources are vital to the sustainability of an enterprise. Hsu, Tian and Xu (2014) advocated that industrial clusters are most conducive to industrial innovation. Professional human resources and firm's performance are positively correlated (Boxall and Purcell, 2011). When the flow of information and human resources is faster, it can help to promote the industrial knowledge spillover effects and strengthen the advantage of industrial innovation. Yang et al. (2020) advocated professional human resources, as one of the four cluster element strategy resources proposed by Michael Porter, as being an element of the competitiveness of an industrial cluster. Hsu, Lain and Lin (2014) emphasized that professional human resources are an essential factor of forming industrial clusters and improving competitiveness. Porter (1985) found that geographic region and the environment of the industry play extremely important roles in determining a cluster's competitive advantage, such as human resources, natural resources, knowledge resources, capital resources and infrastructure. Hence, it can be seen that human resources play a key role in the determination of the competitive advantage of an enterprise.

Boxall and Purcell (2011) discovered that human resources are by far the most essential asset a firm can possess. Jiang et al. (2012) highlights the fact that human capital will never become outmoded and carries value which can adapt and evolve according to transitioning norms and environments. This study incorporates theories put forth by Porter (1985) and Yang et al. (2020) where human resources are the foundation for research in investigating and validating the relationship between organizational performance and human resources. The achievements of supply chain management (SCM) are reliant upon the behaviours of individuals within the companies which comprise the supply chain (SC).

Several researchers posit that HRM is vital as form of support and a system which allows for the operationalization of relationships and duties within the supply chain (Jackson, Schuler and Jiang, 2014). Along this vein, Menon (2012) stresses that certain elements of professional human resources, such as team organization, adaptable job descriptions, teamwork training and the application of performance indicators, have significant correlations with supply chain performance. Liu and Batt (2010) expressly highlights the fact that high-involvement HRM approaches incorporate a collection of HRM practices which function to improve workers' skills, increase employee participation and enrich employee 
incentives. A discerning hiring process ensures that ideal skilled workers are allowed into firms in order to act as essential resources for a company's competitive power (Dubey et al., 2017).

In order to complement selective hiring, organizations must establish various training programs in order to develop employees in terms of skills specific to the firm and develop the breadth and depth of their existing skills. Breadth of skill relates to the acquisition of a variety of abilities which makes an employee proficient in carrying out diverse tasks as required. Depth of skill refers to the attainment of skills which exceed the industrial level and ensure that an employee executes their duties efficiently. Breadth and depth of skill can be obtained through proper training provided by the firm. When combined, they guarantee the creation of skilled employees for organizations, with an emphasis on consistent learning (Liu and Batt, 2010). Employee incentives function to encourage workers to utilize their skills and knowledge to fulfil particular tasks which contribute to the firm's objectives. There are several forms of incentive strategies, including process (Quentier, 2012), performance (Hypko, Tilebein and Gleich, 2010) and goal-based (Sundram et al., 2019; Nguyen, Ha and Doan, 2020) incentives. Shifting environments and integrated manufacturing approaches such as $\mathrm{SCl}$ necessitate flexibility and innovation in employees when facing complicated and unpredictable issues (Chatha and Butt, 2015).

This makes it challenging to assess the work performance and processes of employees. Furthermore, process-based and performance-based incentives which are applied at individual levels have proven to hinder teamwork and collaboration (Hitt, Xu and Carnes, 2016).

P1: $\quad$ There is a positive impact by professional human resource (PHR) on supply chain performance (SCP).

P3: $\quad$ There is an association between professional human resource (PHR) and firm infrastructure (FI).

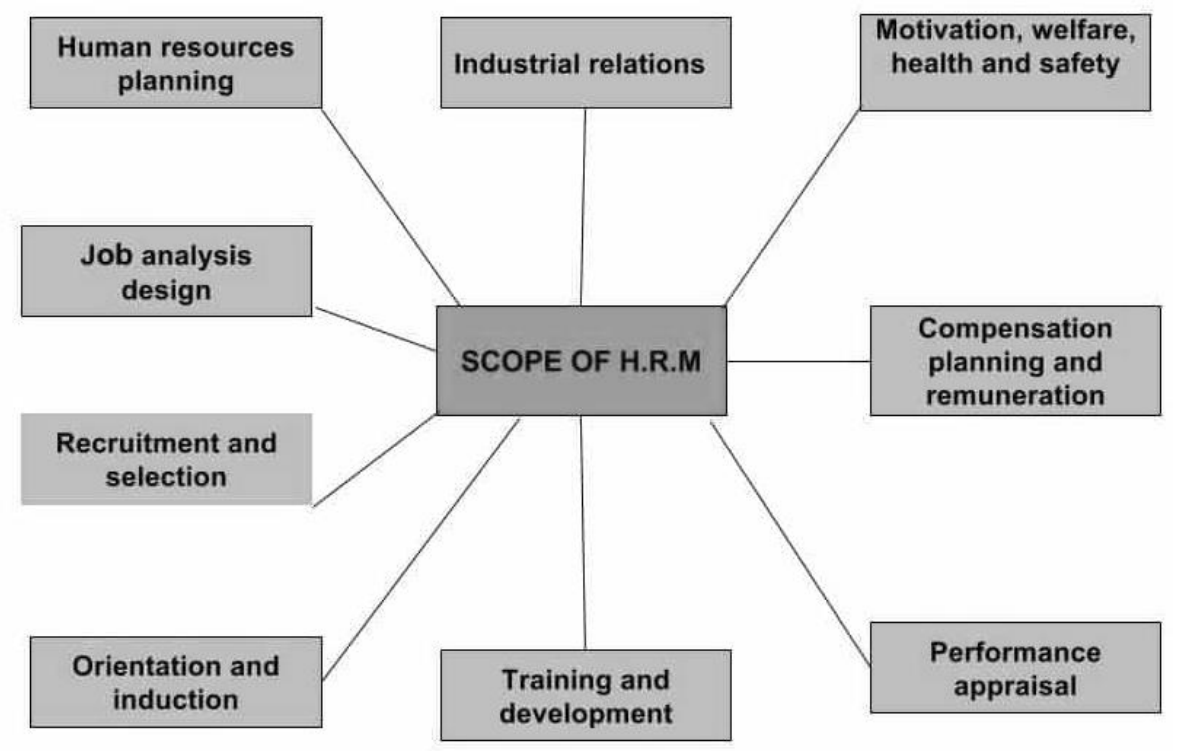

Figure 2. Scope of human resource management

\section{Firm Infrastructure}

Relationships defined by supply chain integration base the selection of supply chain partners on their possession of strategic resources. Resource-based view and Resource Dependence Theory are two theories which help clarify interactions between parties in a 
supply chain. Resource dependence theory in particular asserts that organizations are reliant on other companies in order to acquire essential resources (Emerson, 1962).

One approach in dealing with supply chain dependence is the bilateral hybrid relationship, whereby synchronized efforts are taken to improve the efficiency of both firms in the relationship (Cuong, 2019). Burr (2015) proposes that unbalanced dependencies could damage efforts to create hybrid relationships, and that symmetrical dependence is essential in developing hybrid systems of governance which profit both firms involved (Fawcett et al., 2011; Zacharia, Nix and Lusch, 2011). A method known as "bonding behaviour" (Stylianou, Subramaniam and Niu, 2019) is applied by the firm in the more dependent position in order to restore asymmetrically dependent relationships to a more balanced state of dependence.

For instance, when expecting a higher rate of forthcoming relational exchange (Sashi, 2012), a supplier may choose to invest in technological infrastructure which expedites the precise and appropriate dissemination of information regarding demand forecasting and visibility of supply, thus cutting down the amount of superfluous work for the customer and providing added value to the exchange relationship (Brandenburg et al., 2014). Investing in infrastructure allows the customer to gauge the commitment of the supplier towards facilitating a more effective and efficient connection between them. Brodie et al (2011) posits that the supplier can gain an advantage from the customer's "perception of the effectiveness of the exchange relation".

The RBV (Sundram et al., 2017) asserts that attaining and maintaining competitive advantage is dependent on the company's set of principal competencies which function on the basis of resources that carry the traits of being rare, valuable, hard to substitute, and difficult to imitate. Therefore, the investment in supply chain infrastructure which allows for mutual value creation by amalgamating various processes involving customers offers suppliers with a resource which is both valuable and challenging for rivals to imitate (Sundram et al., 2019).

P2: $\quad$ There is a positive impact by firm infrastructure (FI) on supply chain performance (SCP)

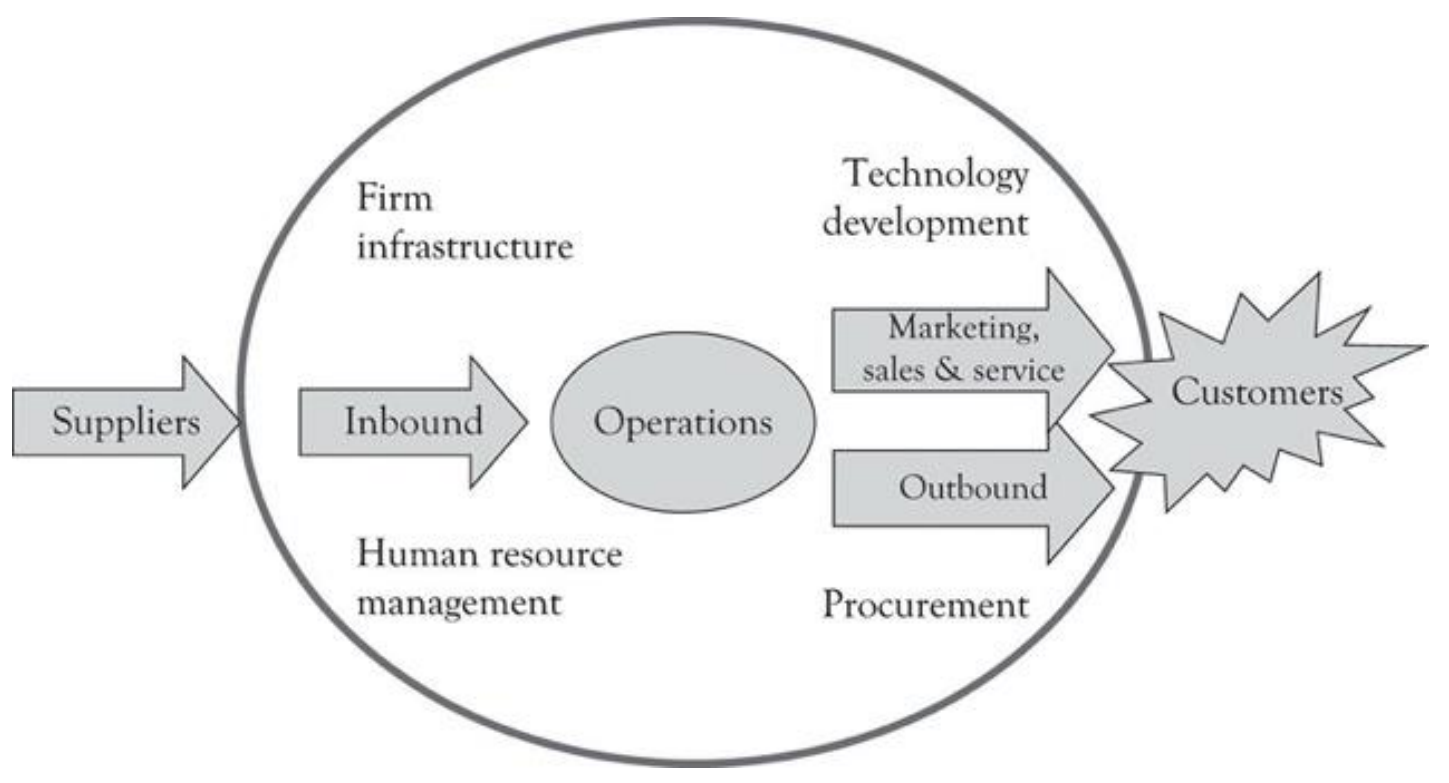

Figure 3. Analytical approach for strategic planning 


\section{Supply Chain Performance}

Measurement of performance, also referred to as management for results, can be defined in various aspects, relying on the method and the reason for measuring that dimension of performance (Koufteros, Verghese and Lucianetti, 2014). As such, performance measurement potentially requires the establishment of expectations, comparison of actual performance with target figures and continually striving to enhance methods and approaches. Thus, performance measurement can be explained as the method of evaluating an individual task or multiple actions in an efficient and effective manner (Wood, Reiners and Srivastava, 2017).

In more exact terms, the measurement of performance is the interpretation of performance results into the form of recorded and communicated information that can be shared and utilized in order to upgrade and enhance operations (Trkman, 2010; Sardi et al., 2020). The significance of supply chains in business competitiveness has given rise to the need for monitoring processes to supervise not only the company's performance, but also that of the supply chain (Estampe et al., 2013). A vigorous performance measurement approach must exhibit characteristics which complement the vigour of its environment (Kim, Kumar and Kumar, 2010). Nudurupati et al. (2011) determines that these characteristics include the capacity to be receptive to fluctuations in the internal and external surroundings of a firm. Supply chain performance is described as the method of quantification of the overall supply chain activities of a firm based on the utilization of capital, cost efficiency and customer service (Al-Hakim and Lu, 2017). Additionally, supply chain performance forecasts various metrics which reveal the tasks related to corrective action, preventive action, and customer service (Hassini, Surti and Searcy, 2012).

The goal of establishing an efficient customer service foundation within a supply chain can be met by implementing corrective action, for example rush order or production overtime. On the other hand, preventive action, which includes extra capacity plant and safety stock, is connected to management of capital and cost operation of the supply chain. When combined, corrective and preventive actions can ensure exceptional customer service. Supply chain management involves an intricate system of business enterprises, existing at multiple tiers along the supply chain, and with varied competencies at each level (Barrat, Choi and Li, 2011; Foerstl et al., 2015). Thus, ascertaining the effective indicators related to supply chain performance is vital as it is dependent on the environment, range, the number of companies and products, and the challenges in creating suitable measures (Chandak, Kumar and Dalpati, 2019).

Rezaei, Celik and Baalousha (2011) proposes that a basic performance measurement framework must contain these essential properties: feedback, data system, accountability, training and recognition. The structure and concept of a supply chain measurement model will be reliant on a firm's goals, and the various strata of management within it (Shepherd and Gunter, 2010). This can be explained by the fact that supply chain performance measures can potentially impact decision-making approaches at different management hierarchies in a company (Askarany, Yazdifar and Askary, 2010). In order to compensate for this, it is necessary to have varied collections of performance measures for each level of management, namely the operational level, strategic level, and tactical level. However, it can be challenging to combine performance measures across all management hierarchy levels. Flynn, Huo and Zhao (2010) asserts that the properties of an efficient performance measurement system must incorporate measurability, universality and consistency which allows for the analysis of the effectiveness of various supply chain performance measures. 


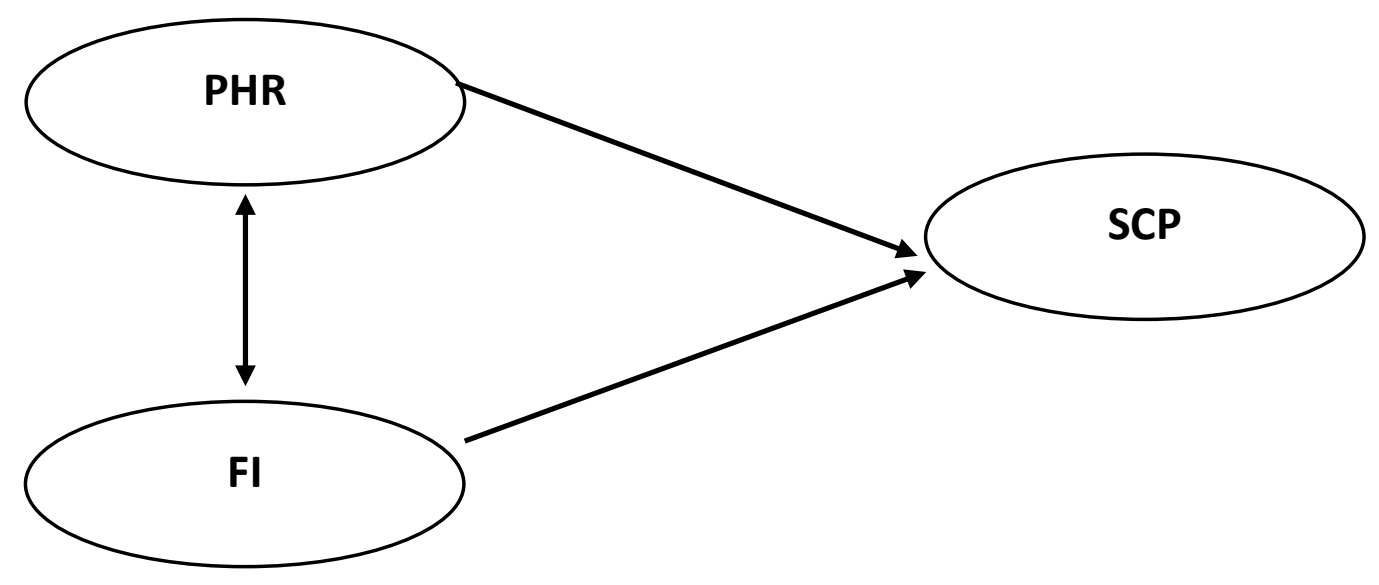

Key: PHR - professional human resource; FI - firm infrastructure; SCP - supply chain performance

Figure 4. Conceptual Framework

\section{Discussion}

The conceptual research has succeeded in revealing results that can contribute to meaningful conclusions. These findings have substantial importance to practitioners and academics in the fields of human resources, supply chain performance and firm infrastructure. The following section details these useful outcomes as contributions to the field, along with the associated theoretical and practical implications. The incorporation of human resource management practices, supply chain performance and firm infrastructure within an organization may certainly overlap with existing systems in the firm. The establishment of these practices must be complemented by the firm's infrastructure which corresponds to the performance of the supply chain.

This may require research focus in terms of discovering ways to prevent conflicts and potential redundancies within a single organization. As such, it is recommended that any firm intending to institute these practices make plans and arrangements to ensure successful operations.

\section{Theoretical Implications}

This study provides a contribution to the existing body of knowledge by exploring the relationships between extensive human resource management practices, firm infrastructure and supply chain management and performance in the context of the Malaysian manufacturing industry. This contribution results from the efforts to assess the effects of human resource management practices and firm infrastructure on supply chain performance. Prior research (Jin et al., 2014; Chin, Tat and Sulaiman, 2015; Nkrumah, Apam and Boadu, 2020; Darwish et al., 2020) have explored the direct relationship between supply chain practices and supply chain performance. Thus, through the appraisal of the potential impact of human resource management practices on supply chain performance in manufacturing industries, this study contributes to the literature relating to resource-based view (RBV) (Caridi et al., 2010).

Furthermore, this study merges the range of variables of human resource management practices and puts them to the test within the same setting. This enables the production of a thorough framework of relationships between all variables. Additionally, this 
study presents both empirical and theoretical cases to validate the existence of the relationships between these variables. This is significant in supporting the research and progression of theories involving relationships between firm infrastructure, human resource management practices and supply chain performance as a whole. This will also aid in the analysis or exploration of the most suitable practices as research variables in different business environments.

\section{Practical Implications}

Advanced knowledge regarding firm infrastructure and professional human resources can be accessed by organizational leaders. This can help management enhance or establish the aforementioned factors in a manner which benefits the firm. The findings of this study can be applied by firm management in advancing business practices in order to create more skilled employees. This study can also assist companies which intend to improve their supply chain performance, or function as a standard to enhance firm infrastructure and professional human resource practices.

Furthermore, this study can help management perceive the significance of human resource practices on supply chain performance, and consequently encourage the organization to be proactive in improving employee satisfaction and participation. In this way, workers can contribute maximum efforts in ensuring stronger supply chain performance.

\section{Conclusion}

This study is among the foremost in determining and conceptually exploring the relationship between firm infrastructure, human resource management practices and supply chain performance. However, the conceptual approach of this study could result in certain limitations. These limitations can be tackled in future research work that employs the variables in this paper, and other connected scopes of research. The first limitation is that of sample size, and it is suggested that future studies apply different sets of data to corroborate the constructs and models in this study. Ideally, future research should aim to obtain data samples which are sufficiently large, so that a complete analysis can be accomplished in a single study. This will allow the researcher to prevent the need for use of certain methods, for example item parcelling.

Additionally, there is a necessity for the examination of other connections between the variables put forward in this study, due to the fact that this paper has not explored all potential connections between the variables. It is also recommended that future research incorporate the elements of IT and current technology, as these are significant components in the modern practice of human resource management and supply chain performance.

The main contribution of the current study is this study is one of the first to discuss the theoretical gap mentioned above. A variety of managerial consequences are offered by this research. First, by defining the professional aspects of human resources and their potential to improve the efficiency of the supply chain of manufacturing firms; by presenting supply chain managers with an outstanding formula for determining the efficacy of professional human resource practices.

Second, the results of this study appear to support the view that the introduction of professional human resource has a substantial effect on the effectiveness of supply chain performance and a direct impact on the performance of manufacturing firms. Third, managers can optimise the firm's infrastructure in tandem with the right professional human resource strategy and subsequently improve the firm's supply chain performance. 
Researchers can use the insights to generate ideas for future research, and senior managers can gain insights into how effective professional human resource practices and firm infrastructure improve supply chain performance.

\section{Reference}

Adams, F. G., Richey Jr, R. G., Autry, C. W., Morgan, T. R., \& Gabler, C. B. (2014). Supply chain collaboration, integration, and relational technology: How complex operant resources increase performance outcomes. Journal of Business Logistics, 35(4), 299-317.

Aguezzoul, A. (2014). Third-party logistics selection problem: A literature review on criteria and methods. Omega, 49, 69-78.

Al-Hakim, L., \& Lu, W. (2017). The role of collaboration and technology diffusion on business performance. International journal of productivity and performance management.

Anastasiou, S. (2012). Critical human resources management functions for efficient logistics and supply chain management. In Proceedings of the 2nd International Conference on Supply Chains, Katerini, Greece.

Askarany, D., Yazdifar, H., \& Askary, S. (2010). Supply chain management, activity- based costing and organisational factors. International journal of production economics, $127(2), 238-248$.

Barnes, J., \& Liao, Y. (2012). The effect of individual, network, and collaborative competencies on the supply chain management system. International Journal of Production Economics, 140(2), 888-899.

Barratt, M., Choi, T. Y., \& Li, M. (2011). Qualitative case studies in operations management: Trends, research outcomes, and future research implications. Journal of Operations Management, 29(4), 329-342.

Boxall, P., \& Purcell, J. (2011). Strategy and human resource management. Macmillan International Higher Education.

Brandenburg, M., Govindan, K., Sarkis, J., \& Seuring, S. (2014). Quantitative models for sustainable supply chain management: Developments and directions. European journal of operational research, 233(2), 299-312.

Brodie, R. J., Hollebeek, L. D., Jurić, B., \& Ilić, A. (2011). Customer engagement: Conceptual domain, fundamental propositions, and implications for research. Journal of service research, 14(3), 252-271.

Burr, V. (2015). Social constructionism. Routledge.

Caridi, M., Crippa, L., Perego, A., Sianesi, A., \& Tumino, A. (2010). Do virtuality and complexity affect supply chain visibility?. International Journal of Production Economics, 127(2), 372-383.

Chaabane, A., Ramudhin, A., \& Paquet, M. (2012). Design of sustainable supply chains under the emission trading scheme.International journal of production economics, 135(1), 3749.

Chandak, A., Kumar, N., \& Dalpati, A. (2019). The Relationship Between Supply Chain Strategy and Supply Chain Performance: An Empirical Investigation Using Structural Equation Modeling. IUP Journal of Supply Chain Management, 16(4).

Chatha, K. A., \& Butt, I. (2015). Themes of study in manufacturing strategy literature. International Journal of Operations \& Production Management.

Chin, T. A., Tat, H. H., \& Sulaiman, Z. (2015). Green supply chain management, environmental collaboration and sustainability performance. Procedia Cirp, 26, 695-699. 
Cuong, H. L. (2019). Relational Capital, Supply Chain Integration and Firm Performance in the Vietnamese Coffee Industry (Doctoral dissertation, The University of Newcastle Australia).

Darwish, S., Alzayed, S., \& Ahmed, U. (2020). How Women in Science can Boost Women's Entrepreneurship: Review and Highlights. International Journal of Innovation Creativity and Change, 14(1), 453-470.

Dubey, R., Gunasekaran, A., Papadopoulos, T., Childe, S. J., Shibin, K. T., \& Wamba, S. F. (2017). Sustainable supply chain management: framework and further research directions. Journal of Cleaner Production, 142, 1119-1130.

Emerson, R. M. (1962). Power-dependence relations. American sociological review, 31-41.

Estampe, D., Lamouri, S., Paris, J. L., \& Brahim-Djelloul, S. (2013). A framework for analysing supply chain performance evaluation models. International Journal of Production Economics, 142(2), 247-258.

Fawcett, S. E., Wallin, C., Allred, C., Fawcett, A. M., \& Magnan, G. M. (2011). Information technology as an enabler of supply chain collaboration: a dynamic- capabilities perspective. Journal of Supply Chain Management, 47(1), 38-59.

Flynn, B. B., Huo, B., \& Zhao, X. (2010). The impact of supply chain integration on performance: A contingency and configuration approach. Journal of operations management, 28(1), 58-71.

Foerstl, K., Azadegan, A., Leppelt, T., \& Hartmann, E. (2015). Drivers of supplier sustainability: Moving beyond compliance to commitment. Journal of Supply Chain Management, 51(1), 67-92.

Fu, D., Ionescu, C. M., Aghezzaf, E. H., \& De Keyser, R. (2014). Decentralized and centralized model predictive control to reduce the bullwhip effect in supply chain management. Computers \& Industrial Engineering, 73, 21-31.

Green, J. K. W., Inman, R. A., Birou, L. M., \& Whitten, D. (2014). Total JIT (T-JIT) and its impact on supply chain competency and organizational performance. International Journal of Production Economics, 147, 125-135.

Harari, M. B., Jain, N. K., \& Joseph, T. (2014). The Five-factor Model of Personality and Knowledge Transfer in the $U$ nited A rab E mirates. International Journal of Selection and Assessment, 22(4), 399-410.

Hassini, E., Surti, C., \& Searcy, C. (2012). A literature review and a case study of sustainable supply chains with a focus on metrics. International Journal of Production Economics, 140(1), 69-82.

Hendiani, S., Liao, H., \& Jabbour, C. J. C. (2020). A new sustainability indicator for supply chains: theoretical and practical contribution towards sustainable operations. International Journal of Logistics Research and Applications, 1-26.

Hitt, M. A., Xu, K., \& Carnes, C. M. (2016). Resource based theory in operations management research. Journal of Operations Management, 41, 77-94.

Hsu, M. S., Lai, Y. L., \& Lin, F. J. (2014). The impact of industrial clusters on human resource and firms performance. Journal of Modelling in Management.

Hsu, P. H., Tian, X., \& Xu, Y. (2014). Financial development and innovation: Cross-country evidence. Journal of Financial Economics, 112(1), 116-135.

Hua, N., Huang, A., Medeiros, M., \& DeFranco, A. (2020). The moderating effect of operator type: the impact of information technology (IT) expenditures on hotels' operating performance.International Journal of Contemporary Hospitality Management. 
Huang, M. C., Yen, G. F., \& Liu, T. C. (2014). Re-examining supply chain integration and the supplier's performance relationships under uncertainty. Supply Chain Management: An International Journal.

Huselid, M. A. (1995). The impact of human resource management practices on turnover, productivity, and corporate financial performance. Academy of management journal, 38(3), 635-672.

Hypko, P., Tilebein, M., \& Gleich, R. (2010). Benefits and uncertainties of performance-based contracting in manufacturing industries. Journal of Service Management, 21(4), 460.

Jackson, S. E., Schuler, R. S., \& Jiang, K. (2014). An aspirational framework for strategic human resource management. Academy of Management Annals, 8(1), 1-56.

Jang, S., \& Ardichvili, A. (2020). Examining the Link Between Corporate Social Responsibility and Human Resources: Implications for HRD Research and Practice. Human Resource Development Review, 1534484320912044.

Jermsittiparsert, K., Wattanapongphasuk, S., \& Phonwattana, S. (2019). The Impact of Supply Chain Capabilities on the Performance of Food Industry in Thailand. Int. J Sup. Chain. Mgt Vol, 8(3), 131.

Jiang, K., Lepak, D. P., Hu, J., \& Baer, J. C. (2012). How does human resource management influence organizational outcomes? A meta-analytic investigation of mediating mechanisms. Academy of management Journal, 55(6), 1264-1294.

Jin, Y., Vonderembse, M., Ragu-Nathan, T. S., \& Smith, J. T. (2014). Exploring relationships among IT-enabled sharing capability, supply chain flexibility, and competitive performance. International Journal of Production Economics, 153, 24-34.

Khajavi, S. H., Partanen, J., \& Holmström, J. (2014). Additive manufacturing in the spare parts supply chain. Computers in industry, 65(1), 50-63.

Kim, D. Y., Kumar, V., \& Kumar, U. (2010). Performance assessment framework for supply chain partnership. Supply Chain Management: An International Journal.

Koufteros, X., Verghese, A. J., \& Lucianetti, L. (2014). The effect of performance measurement systems on firm performance: A cross-sectional and a longitudinal study. Journal of operations Management, 32(6), 313-336.

Liu, X., \& Batt, R. (2010). How supervisors influence performance: A multilevel study of coaching and group management in technology-mediated services. Personnel Psychology, 63(2), 265-298.

MacDuffie, J. P. (1995). Human resource bundles and manufacturing performance: Organizational logic and flexible production systems in the world auto industry. $\mathrm{Ilr}$ Review, 48(2), 197-221.

Menon, S. T. (2012). Human resource practices, supply chain performance, and wellbeing. International Journal of Manpower, 33(7), 769-785.

Mkumbo, F. A. E., Ibrahim, A. R., Salleh, A. L., Sundram, V. P. K., \& Atikah, S. B., (2019). The Influence of Supply Chain Practices and Performance Measurement Practices towards Firm Performance, International Journal of Supply Chain Management, Vol. 8 (3), 809819.

Nguyen, H., Ha, H., \& Doan, T. (2020). The impact of supply chain quality management on firm performance: Empirical evidence from Vietnam. Uncertain Supply Chain Management, 8(2), 331-350.

Nkrumah, S. K., Apam, J., \& Boadu, P. (2020). Enhancing Operational Performance through Supply Chain Management Practices: Evidence from Firms in the Petroleum Downstream. Journal of Economics, Management and Trade, 34-46. 
Nudurupati, S. S., Bititci, U. S., Kumar, V., \& Chan, F. T. (2011). State of the art literature review on performance measurement.Computers \& Industrial Engineering, 60(2), 279-290.

Nyaga, G. N., Whipple, J. M., \& Lynch, D. F. (2010). Examining supply chain relationships: do buyer and supplier perspectives on collaborative relationships differ?. Journal of operations management, 28(2), 101-114.

Ou, C. S., Liu, F. C., Hung, Y. C., \& Yen, D. C. (2010). A structural model of supply chain management on firm performance. International Journal of Operations \& Production Management.

Porter, M. E. (1985). Value chain. The Value Chain and Competitive advantage: creating and sustaining superior performance.

Quentier, J. M. (2012). Self-employment start-ups and value creation: An empirical analysis of German micro data. Journal of Competitiveness Studies, 20(1/2), 37.

Rajagopal, P., Nur Atiqah, Z. A., Atikah, S. B., Appasamy, G., \& Sundram, V. P. K., (2016), "Determinants of Supply Chain responsiveness among Firms in the Manufacturing Industry in Malaysia.", International Journal of Supply Chain Management, Vol. 5, (3)

Rajesh, R., \& Ravi, V. (2015). Supplier selection in resilient supply chains: a grey relational analysis approach. Journal of Cleaner Production, 86, 343-359.

Ralston, P. M., Blackhurst, J., Cantor, D. E., \& Crum, M. R. (2015). A structure- conductperformance perspective of how strategic supply chain integration affects firm performance. Journal of Supply Chain Management, 51(2), 47-64.

Rezaei, A. R., Celik, T., \& Baalousha, Y. (2011). Performance measurement in a quality management system. Scientia Iranica, 18(3), 742-752.

Sardi, A., Sorano, E., Garengo, P., \& Ferraris, A. (2020). The role of HRM in the innovation of performance measurement and management systems: a multiple case study in SMEs. Employee Relations: The International Journal.

Sashi, C. M. (2012). Customer engagement, buyer-seller relationships, and social media. Management decision.

Saudi, M. H. M., Juniati, S., Kozicka, K., \& Razimi, M. S. A. (2019). Influence of lean practices on supply chain performance.Polish Journal of Management Studies, 19.

Selvaraju, M., Beleya, P., \& Sundram, V. P. K., (2017), Supply Chain Cost Reduction using Mitigation \& Resilient Strategies in the Hypermarket Retail Business, International Journal of Supply Chain Management, Vol. 6 (2), 116-121.

Selvaraju, M., Chan, C., Jie, F., \& Sundram, V. P. K. (2019) Halal Accreditation and Certification in a Non-Muslim Country Setting: Insights from Australia Halal Meat Supply Chain. International Journal of Supply Chain Management, Vol. 8 (1), 10-17.

Shabbir, M. S., \& Kassim, N. M. (2018). Supply chain management drivers and sustainability of green initiatives in manufacturing enterprises: A case in Pakistan. International Journal of Entrepreneurship, 22(15), 1-19.

Shepherd, C., \& Gunter, H. (2010). Measuring supply chain performance: current research and future directions. In Behavioral Operations in Planning and Scheduling (pp. 105-121). Springer, Berlin, Heidelberg.

Stylianou, A., Subramaniam, C., \& Niu, Y. (2019). The Role of Knowledge Management in the Relationship between IT Capability and Interorganizational Performance: An Empirical Investigation. Communications of the Association for Information Systems, 45(1), 4.

Sundram, V. P. K., Atikah, S. B., Akmal, A. O., \& Zarina, A. M. (2017), Green Supply Chain Management Practices in Malaysia Manufacturing Industry, International Journal of Supply Chain Management, Vol. 6, (2), 89-95. 
Sundram, V. P. K., Atikah, S. B., Chandran, V. G. R. (2016). Supply Chain Management: Principles, Measurement and Practice. University of Malaya Press, Kuala Lumpur.

Sundram, V. P. K., Atikah, S. B., Hafiz, M. Z., Azimah, D., Shahrin, N., and Thirunavukkarasu, K. (2017). Supply Chain Logistics: A Malaysian Perspective, Petaling Jaya, Selangor Malaysian Logistics and Supply Chain Association (MLSCA).

Sundram, V. P. K., Ibrahim, I., Mashitah, M. E., Natasya, N. M. A. (2019). The Issues in Order Picking and Packaging in a Leading Pharmaceutical Company in Malaysia. International Journal of Supply Chain Management, Vol. 8 (6), 1055-1061

Swart, J., \& Kinnie, N. (2014). Reconsidering boundaries: Human resource management in a networked world. Human Resource Management, 53(2), 291- 310.

Trkman, P. (2010). The critical success factors of business process management. International journal of information management, 30(2), 125- 134.

Wong, C. Y., \& Karia, N. (2010). Explaining the competitive advantage of logistics service providers: A resource-based view approach. International Journal of Production Economics, 128(1), 51-67.

Wood, L. C., Reiners, T., \& Srivastava, H. S. (2017). Think exogenous to excel: alternative supply chain data to improve transparency and decisions. International Journal of Logistics Research and Applications, 20(5), 426-443.

Yang, Y., Antonio, K. W., Lee, L. P. K., \& Cheng, T. C. E. (2020). The performance implication of corporate social responsibility in matched Chinese small and medium-sized buyers and suppliers.International Journal of Production Economics, 107796.

$\mathrm{Yu}, \mathrm{W}$. (2015). The effect of IT-enabled supply chain integration on performance. Production Planning \& Control, 26(12), 945-957.

Zacharia, Z. G., Nix, N. W., \& Lusch, R. F. (2011). Capabilities that enhance outcomes of an episodic supply chain collaboration.Journal of operations Management, 29(6), 591-603. 